\title{
Analytical study of correlating of investigational modalities with clinical diagnosis of benign breast diseases with special reference to fine needle aspiration cytology
}

\author{
Ramesh Sagar*, Abdul Azeem Gaddikeri, Vijay Kumar Rathod
}

Department of Surgery, Raichur Institute of Medical sciences, Raichur, Karnataka, India

Received: 11 June 2015

Revised: 23 June 2015

Accepted: 11 July 2015

*Correspondence:

Dr. Ramesh Sagar,

E-mail: rameshcsagar@gmail.com

Copyright: ( $)$ the author(s), publisher and licensee Medip Academy. This is an open-access article distributed under the terms of the Creative Commons Attribution Non-Commercial License, which permits unrestricted non-commercial use, distribution, and reproduction in any medium, provided the original work is properly cited.

\section{ABSTRACT}

Background: Diagnosis of benign breast disorder (BBD) by Fine needle aspiration cytology (FNAC) is a time tested non-invasive method.

Methods: Patients with benign breast diseases in age group between 15 to 35 years were included in the study. Patients with malignant breast diseases or having infectious disorders of breasts were excluded from the study. This survey was mainly meant for studying different types of benign diseases of the breast, their pathology with special reference to FNAC.

Results: FNAC was consistent in $90.62 \%$ of cases of fibroadenoma, 1 case $(3.12 \%)$ each was documented as benign subareolar papillomatosis, benign epithelial hyperplasia and benign ductal cells. Out of 28 cases diagnosed clinically as fibroadenoma $24(85.71 \%)$ were cytologically correct.

Conclusions: FNAC is a most accurate, safe, cost effective and easy method to confirm the diagnosis of most benign breast diseases with good sensitivity. Surgical Excision is the main stay of treatment for most benign breast diseases.

Keywords: Fine needle aspiration cytology, Breast disorder, Fibroadenoma, Cystosarcoma phylloides

\section{INTRODUCTION}

Literature on benign breast disorders and diseases in India is scanty. The vast majority of the lesions that occur in the breast are benign. Until recently benign disorders of the breast were regarded as relatively unimportant, far more attention was focused on breast cancer. This has resulted in many patients with benign breast disease receiving rather scant attention from clinicians. Benign breast disease has also suffered from the major disadvantage of confusing terminology, inadequate classification and poor correlation between clinical, radiological and pathological features. ${ }^{1}$
Being alert to breast changes and conducting detailed examination and specific investigations one can diagnose most benign breast diseases. During the past decade there has been increasing interest in benign breast disease form a number of reasons. As patients demand investigation and treatment for symptoms of benign breast disease. Benign breast disorder (BBD) can be defined as any nonmalignant breast condition and encompasses a wide range of clinical and pathologic disorders. Even clinical diagnosis remains simple, pathological evaluation of each condition should be undertaken. Exclusion of carcinoma and specific pathological diagnosis of benign disease can make management of condition, easy, feasible, and highly economic. Although BBD is not life threatening, clinicians require an in-depth understanding of its 
significance so that clear explanations can be given to affected patients, appropriate treatment can be instituted, and unnecessary long-term follow-up can be avoided. ${ }^{2}$ Present study was aimed to evaluate benign breast diseases using various investigations and to evaluate diagnostic significance of histopathological examination with special reference to fine needle aspiration cytology.

\section{METHODS}

Present prospective study was conducted in VIMS Hospital Bellary during the year November 2006 to October 2007. Patients with benign breast diseases in age group between 15 to 35 years were included in the study. Patients with malignant breast diseases or having infectious disorders of breasts were excluded from the study. This survey was mainly meant for studying different types of benign diseases of the breast, their pathology with special reference to FNAC and to evaluate the various modes of management.

\section{RESULTS}

In present study, 50 cases were examined, investigated and analyzed. After verifying with histo-pathological diagnosis, we found that USG of the breast was able to detect 24 out of 32 cases of fibroadenoma correctly i.e. in $75 \%$ of cases, 5 out of 10 cases of cystosancoma phylloides were detected by USG correctly i.e. in $50 \%$ of cases. All clinically solid lesions were solid on USG, but $60 \%$ of clinically cystic lesions were solid on USG. 32 cases of fibroadenoma were documented histopathologically; FNAC was consistent in $90.62 \%$ of cases, 1 case $(3.12 \%)$ each was documented as benign subareolar papillomatosis, benign epithelial hyperplasia and benign ductal cells.

Out of 28 cases diagnosed clinically as fibroadenoma 24 $(85.71 \%)$ were cytologically correct. Intracanalicular type was the common type of fibroadenoma seen in 28 cases out of 32 cases $(87.50 \%)$ in histopathology report.

Table 1: Ultrasound and clinical correlation to differentiate cystic from solid lesions.

\begin{tabular}{|lll|}
$\begin{array}{l}\text { Clinical } \\
\text { Diagnosis }\end{array}$ & $\begin{array}{l}\text { USG } \\
\text { Solid lesion }\end{array}$ & $\begin{array}{l}\text { USG } \\
\text { Cystic lesion }\end{array}$ \\
\hline Solid lesion(45) & 45 & - \\
\hline Cystic lesion(5) & 3 & 2 \\
\hline Total & 48 & 2 \\
\hline
\end{tabular}

After taking the history, a general examination of the patient was done and general condition noted. A detailed local examination of presenting lesion was then carried out and a diagnosis arrived at. After routine haematological and urine examination, patients were subjected to specific investigation like ultrasonography of the breast and FNAC of the lump. All patients underwent operative treatment either in the form of excision biopsy or enucleation or wide excision or simple mastectomy. The excised specimen was sent for histo-pathological examination for confirmation of clinical diagnosis. All the patients were followed up for 6 months periods for evidence of recurrence. Clinical diagnosis, FNAC, USG, and histo-pathological diagnosis were compared and analyzed.

Table 2: USG correlation of benign breast lesions.

\begin{tabular}{|lllll|l|}
\hline Histology & Fibroadenoma & $\begin{array}{l}\text { Cystosarcoma } \\
\text { phylloides }\end{array}$ & Lipoma & Galactocele & Others \\
\hline Fibroadenoma(32) & $24(75 \%)$ & $2(6.25 \%)$ & $6(18.75 \%)$ & - & - \\
\hline Cystosarcoma phylloides(10) & $3(30 \%)$ & $5(50 \%)$ & $2(20 \%)$ & - & - \\
\hline Galactocele (2) & - & - & - & $2(100 \%)$ & - \\
\hline Lipoma(2) & - & - & $2(100 \%)$ & - & - \\
\hline Tubular adenoma(2) & $2(100 \%)$ & - & - & - & - \\
\hline Ductal ectasia(2) & $1(50 \%)$ & - & $1(50 \%)$ & - & - \\
\hline
\end{tabular}

\section{DISCUSSION}

Benign Breast Disease a common disease affecting women in our country. According to the Statistics obtained from VIMS hospital Bellary, the majority of diseases affecting the female breast were benign disease.

All the cases in present study were subjected to Ultrasonography (USG) of the breasts. After verifying with histopathological diagnosis, it was found that Ultrasonography of the breasts was able to detect 24 out of 32 cases of fibroadenoma correctly i.e., in $(75 \%)$ of cases, 5 out of 10 cases cystosarcoma phylloides were detected by Ultrasonography correctly i.e. $50 \%$ of cases.
Ultrasonography was very useful in detecting solid from cystic lesions of the breast.

In present study FNAC correctly diagnosed $90.62 \%$ of cases of fibroadenomas. Linsk et al, reported an accuracy of $60.4 \%$ in $1972 .{ }^{3}$ Hand Uma et al reported in their series of 360 fine needle aspirations as FNAC has efficiency of $98.3 \%$ in diagnosis. ${ }^{4}$ Of the 10 cases of cystosarcoma phylloides, FNAC correctly diagnosed 6 cases $(60 \%)$ as benign phylloides tumour. 3 cases $(30 \%)$ were misdiagnosed as fibroadenoma and 1 cases $(10 \%)$ was reported as benign epithelial hyperplasia. 
In this study, all the FNAC reports were indicative of the benign nature of lesions. As the number of Cases studied in this series is small, further study is required with a larger number of cases to find out the diagnostic accuracy of FNAC in differentiating benign from malignant tumours of the breast.

Table 3: Cyto-histological correlation in benign breast diseases.

\begin{tabular}{|c|c|c|c|c|c|c|}
\hline \multirow{2}{*}{ Histological diagnosis } & \multicolumn{6}{|c|}{ Cytological diagnosis } \\
\hline & F.A (\%) & $\begin{array}{l}\text { C.S.P. } \\
(\%)\end{array}$ & $\begin{array}{l}\text { B.S.P. } \\
(\%)\end{array}$ & $\begin{array}{l}\text { B.E.H. } \\
(\%)\end{array}$ & $\begin{array}{l}\text { B.D.C. } \\
(\%)\end{array}$ & $\begin{array}{l}\text { N.S.M. } \\
(\%)\end{array}$ \\
\hline $\begin{array}{l}\text { Fibroadenoma } \\
\text { (32 cases) }\end{array}$ & $\begin{array}{l}29 \\
(90.62 \%)\end{array}$ & - & $\begin{array}{l}1 \\
(3.12 \%)\end{array}$ & $\begin{array}{l}1 \\
(3.12 \%)\end{array}$ & $\begin{array}{l}1 \\
(3.12 \%)\end{array}$ & - \\
\hline $\begin{array}{l}\text { Cystosarcoma phylloides } \\
\text { ( } 10 \text { cases) }\end{array}$ & $\begin{array}{l}3 \\
(30 \%)\end{array}$ & $\begin{array}{l}6 \\
(60 \%)\end{array}$ & - & $\begin{array}{l}1 \\
(10 \%)\end{array}$ & - & - \\
\hline Galactocele ( 2 cases $)$ & - & - & - & - & $2(100 \%)$ & - \\
\hline Lipoma ( 2 cases $)$ & - & - & - & - & - & $2(100 \%)$ \\
\hline $\begin{array}{l}\text { Tubular adenoma } \\
\text { ( } 2 \text { cases })\end{array}$ & $\begin{array}{l}2 \\
(100 \%)\end{array}$ & - & - & - & - & - \\
\hline $\begin{array}{l}\text { Ductal ectasia } \\
\text { ( } 2 \text { cases })\end{array}$ & - & - & - & - & 2 & - \\
\hline Total & 34 & 6 & 1 & 2 & 5 & 2 \\
\hline
\end{tabular}

Table 4: Clinico-cytological correlation in benign breast diseases.

\begin{tabular}{|c|c|c|c|c|c|c|}
\hline \multirow{2}{*}{$\begin{array}{l}\text { Clinical } \\
\text { Diagnosis }\end{array}$} & \multicolumn{6}{|c|}{ Cytological diagnosis } \\
\hline & FA $(\%)$ & $\operatorname{CSP}(\%)$ & B.S.P (\%) & BEH (\%) & BDC (\%) & $\begin{array}{l}\text { N.S.M } \\
(\%)\end{array}$ \\
\hline $\begin{array}{l}\text { Fibroadenoma } \\
\text { ( } 28 \text { cases })\end{array}$ & $24(85.71 \%)$ & - & $\begin{array}{l}1 \\
(3.57 \%)\end{array}$ & $\begin{array}{l}1 \\
(3.57 \%)\end{array}$ & $\begin{array}{l}2 \\
(7.14 \%)\end{array}$ & - \\
\hline $\begin{array}{l}\text { Cystosarcoma } \\
\text { Phylloides } \\
\text { (12 cases) }\end{array}$ & $\begin{array}{l}7 \\
(58.33 \%)\end{array}$ & $\begin{array}{l}5 \\
(41.66 \%)\end{array}$ & - & - & - & - \\
\hline $\begin{array}{l}\text { Galactocele } \\
(2 \text { cases })\end{array}$ & - & - & - & - & $\begin{array}{l}1 \\
(50 \%)\end{array}$ & $\begin{array}{l}1 \\
(50 \%)\end{array}$ \\
\hline $\begin{array}{l}\text { Fibroadenosis } \\
\text { ( } 3 \text { cases })\end{array}$ & - & $\begin{array}{l}1 \\
(33.33 \%)\end{array}$ & - & $\begin{array}{l}1 \\
(33.33 \%)\end{array}$ & - & $\begin{array}{l}1 \\
(33.33 \%)\end{array}$ \\
\hline $\begin{array}{l}\text { Ductal Ectasia } \\
(2 \text { cases })^{\prime}\end{array}$ & - & - & - & - & $\begin{array}{l}2 \\
(100 \%)\end{array}$ & - \\
\hline $\begin{array}{l}\text { Breast Cyst } \\
(3 \text { cases })\end{array}$ & $\begin{array}{l}3 \\
(100 \%)\end{array}$ & - & - & - & - & - \\
\hline Total & 34 & 6 & 1 & 2 & 5 & 2 \\
\hline
\end{tabular}

Fibroadenoma, CSP-Cystosarcoma phylloides, BSP-Benign subareolar papillomatosis, BEH-Benign Epithelial hyperplasia, BDC - Benign ductal cells, NSM -Nonspecific mastitis.

Table 5: Histopathological types of fibroadenoma.

\begin{tabular}{|lll|} 
Types & No. of Cases & $\%$ \\
\hline Intracanalicular & 28 & $87.50 \%$ \\
\hline Pericanalicular & 3 & $9.37 \%$ \\
\hline Both & 1 & $3.12 \%$ \\
\hline
\end{tabular}

cases of cystosarcoma phylloides, 8 cases underwent excision with $2 \mathrm{~cm}$ margin and on histopathological

In present study, all the 32 cases of fibroadenoma underwent excision. 2 cases of bilateral fibroadenoma underwent bilateral excision. The incisions used were either a subareolar or semicircular incision and radial incision following the natural lines in the skin. Of the 10 examination margins were found to be negative. 2 cases underwent simple mastectomy. Two cases of each 
Galactocele, Lipoma, Tubular adenoma and Ductal Ectasia underwent excision. A drain was kept for all cases which were removed after 48 hours. Postoperatively patients were put on antibiotics and analgesics.

Table 6: Types of treatment of benign breast diseases.

\begin{tabular}{|lll|}
\hline Disease & Excision & $\begin{array}{l}\text { Simple } \\
\text { Mastectomy }\end{array}$ \\
\hline Fibroadenoma & 32 & - \\
\hline $\begin{array}{l}\text { Cystosarcoma } \\
\text { Phylloides }\end{array}$ & 8 & 2 \\
\hline Galactocele & 2 & - \\
\hline Lipoma & 2 & - \\
\hline $\begin{array}{l}\text { Tubular } \\
\text { Adenoma }\end{array}$ & 2 & - \\
\hline Ductal Ectasia & 2 & - \\
\hline Total & 48 & 2 \\
\hline
\end{tabular}

Sutures were removed after 7 days and none of the cases had wound infection of gaping. A fair attempt was made to follow up the cases, but it was very disappointing and very few cases attended the outpatient in response to the appeal made to them. Recurrence of the lesions was not noticed in any of the patients who came for follow up for periods up to 6 months. Haagensen ${ }^{5}$ has reported recurrence of benign breast tumours to be very rare in a period of 3 years. It is mainly because of a smaller lesion being unnoticed during the first operation. Foster M.E et al reported in their series that recurrence of fibroadenomas was related to inadequate primary excision or the development of a new lesion and the mean time for development of new lesions was over 4 years. ${ }^{6}$ another series reports a recurrence rate for these lesions within the range of $1.5 \%$. Moffat and colleagues have reported incomplete excision of phylloides tumours as a major determinant for local recurrence.

\section{CONCLUSIONS}

In the present study fibroadenoma is the most common benign breast disease. FNAC is a most accurate, safe, cost effective and easy method to confirm the diagnosis of most benign breast diseases with good sensitivity. Surgical Excision is the main stay of treatment for most benign breast diseases. Wide excision and simple mastectomy may be needed in some cases of cystosarcoma phylloides. There is good correlation between clinical diagnosis and FNAC and also between FNAC and Histology. Ultrasonography of breast is a better supportive investigation especially when differentiating solid from cystic lesion. Finally, clinical diagnosis is consistent with FNAC and Histology in substantial number of cases.

\section{Funding: No funding sources \\ Conflict of interest: None declared}

Ethical approval: The study was approved by the institutional ethics committee

\section{REFERENCES}

1. Greenall Michael J. "Benign condition of the breast" Chapter-12.1, Oxford text book of surgery Peter J. Morris and Ronald A. Malt Eds, New York: Oxford Medical Publication, 1994;789-807.

2. Beenken Samuel W, Bland Kirby I "Evaluation and Treatment of Benign Breast Disorders" Chapter 9, The Breast-Comprehensive Management of Benign and Malignant Disorders. 2004;3(1):22-3.

3. Linsk JA, Franzen S. Clinical aspiration cytology; Philadelphia J.P. Lippincott 1983; 105-137.

4. Hand U, Mohan H. Fine Needle Aspiration as a Diagnostic Tool in Breast Lesions. Indian Journal of Surgery. 2000;62(2):125-8.

5. Haagensen CD: "Anatomy of the mammary glands", In Haagensen CD: Diseases of the breast, Ed 3, Philadelphia, 1986, WB Saunders.

6. Foster ME, Garrahan N, Williams S. Fibroadenoma of the breast: A clinical and pathological study. Journal of the Royal College of Surgeons of Edinburgh. 1988;33(1):16-9.

7. Moffat $\mathrm{C}$ et al: Phylloides tumour of the breast: a clinico-pathological review of thirty-two cases, Histopathology. 1995;27:205.

Cite this article as: Sagar R, Gaddikeri AA, Rathod VK. Analytical study of correlating of investigational modalities with clinical diagnosis of benign breast diseases with special reference to fine needle aspiration cytology. Int J Adv Med 2015;2:227-30. 